\title{
Pembentukan Facebook News Room Dalam Menekan Kasus Rasisme
}

\author{
Ina Novita Sari ${ }^{1}$, Tiara Pratiwi ${ }^{2}$ \\ London School of Public Relations Communication \& Business Institute \\ Email: inanovita97@gmail.com
}

\begin{abstract}
ABSTRAK
Komunikasi terapeutik adalah upaya penyembuhan melalui komunikasi. Pada kasus terapi anak Down Syndrome, Berdasarkan kasus kematian Goerge Floyd di Minneapolis, Amerika Serikat yang menimbulkan reaksi keras banyak kalangan di Amerika Serikat dan media dunia menyoroti kasus ini hingga memunculkan tagar \#BlackLivesMatter di media sosial, Facebook dikabarkan memulai tindakan melabeli konten berita yang berasal dari media asing seperti Rusia, China, Korea Utara, dan Iran melalui fitur Facebook Newsroom, yang bertujuan sebagai upaya Facebook mereduksi saluran media asing yang dikendalikan oleh negara serta meredam aktivitas pemberitaan yang berpotensi mendorong informasi palsu. Pemberian label laman 'media asing' ini didasarkan pada berbagai faktor, seperti informasi kepemilikan hingga kebijakan koreksi. Penelitian ini bertujuan untuk mengetahui pembentukan dan efektivitas Facebook Newsroom dalam menekan kasus rasisme, berfokus pada pemberian label pada media asing dengan menggunakan penelitan kualitatif deskriptif dan observasi sebagai unit analisis. Hasil penelitian ini menemukan bahwa Facebook Newsroom merupakan strategi Facebook untuk menyaring informasi yang dikonsumsi oleh penggunanya. Namun setelah satu bulan launcing di Amerika Serikat, Facebook masih dinilai memiliki masalah yang sama yakni misinformasi dan tempat seseorang menyebarkan ujaran kebencian. Sampai saat ini dapat dinyatakan bahwa tindakan ini tidak cukup berarti untuk meredam amarah publik dan mengembalikan kepercayaan dari pengiklan. Bila tidak ada perubahan dalam waktu dekat, Facebook bisa saja ditinggalkan oleh pengguna karena kehilangan kredibilitas.
\end{abstract}

Kata Kunci: Strategi Facebook, Kasus Rasisme, Facebook News Room

\section{Establishment of Facebook News Room in Suppressing Racism Cases}

\begin{abstract}
Based on the case of Goerge Floyd's death in Minneapolis, the United States which caused a strong reaction in the United States and media in the world highlighting this case which led to the hashtag \#BlackLivesMatter on social media, Facebook reportedly started an act of labeling news content from foreign media such as Russia, China, North Korea, and Iran through the Facebook Newsroom feature, which aims to reduce foreign media channels controlled by the state and curb news activities that could potentially encourage false information. The labeling as "foreign media" based on various factors, such as ownership information. This study aims to determine the formation and effectiveness of Facebook Newsroom in suppressing racism cases, focusing on labeling foreign media, using descriptive qualitative and observation as the unit of analysis. The results found that Facebook Newsroom is Facebook's strategy to filter information consumed by its users. But after one month of launching, Facebook still considered having the same problem, namely misinformation and where someone spreads hate speech. It could be argued that these actions were insufficient to quell public anger and restore the trust of advertisers. If nothing changes soon, Facebook could be abandoned by users because it loses credibility
\end{abstract}

Keywords: Facebook's Strategy, Rasism Case, Facebook News Room 
Korespondensi: Ina Novita Sari, Tiara Pratiwi. London School of Public Relations Communication \& Business Institute. Jl. K.H. Mas Mansyur, Kav 35, Jakarta Pusat, Indonesia, 10220. (+62)85245700637, inanovita97@ gmail.com, tiara.pratiwi84@gmail.com

\section{PENDAHULUAN}

Berangkat dari sebuah kasus kematian pria berkulit hitam bernama Goerge Floyd akibat lehernya ditindih dengan lutut seorang polisi berkulit putih di Minneapolis, Amerika Serikat ini menimbulkan reaksi keras dari banyak kalangan di Amerika Serikat dan banyak media dunia yang menyoroti kasus ini hingga memunculkan tagar \#BlackLivesMatter di media sosial (Iswara, 2020).

Kasus ini telah mengguncang 30 negara bagian di Amerika Serikat dalam aksi protes serta memicu aksi demonstrasi di negara lain seperti Jerman, Italia, hingga Irlandia hingga New York Times menyebut aksi protes dan demonstrasi ini sebagai kemarahan global (Amali, 2020).

Ditengah semakin memanasnya situasi di Amerika Serikat, media sosial Facebook dikabarkan mulai melakukan tindakan melabeli konten berita yang berasal dari media asing seperti Rusia, China, Korea Utara, dan Iran di platform ini. Seperti dikutip dari The Verge, tindakan ini dilakukan sebagai upaya Facebook untuk mereduksi saluran media asing yang dikendalikan oleh negara dan bertujuan untuk meredam aktivitas pemberitaan yang berpotensi mendorong informasi palsu (VOI, 2020).

Pemberian label laman 'media asing' ini didasarkan pada berbagai faktor, mulai dari informasi kepemilikan dan pendanaan, transparansi disekitar sumber tulisan, hingga kebijakan koreksi dan sistem akuntabilitas media tersebut. Meski mendapatkan label 'media asing' pada platform
Facebook, laman media yang mendapatkan label tersebut masih dapat beroperasi secara independen, berdasarkan kebijakan undang - undang kebebasan pers dan penilaian yang kredible dari media asing tersebut (VOI, 2020).

Facebook telah melabeli beberapa laman dan unggahan dari outlet media asing karena dianggap menyebarkan propaganda di Amerika Serikat. Beberapa di antara media tersebut termasuk media asing dari Rusia seperti Sputnik dan RT. Kedua media ini, didefinisikan sebagai media yang dikendalikan oleh negara, bersama dengan outlet media lain seperti China Daily oleh Facebook (VOI, 2020).

Facebook pun berencana akan mulai memberikan label iklan pada laman media asing dalam beberapa bulan mendatang serta juga mempertimbangkan untuk turut memberikan label pada berita yang dibagikan secara individual pada timeline seseorang (VOI, 2020).

Selain memberikan label 'media asing' pada media yang dianggap dikendalikan oleh suatu negara, guna semakin menekan pemberitaan yang dapat berpotensi meningkatkan jumlah dan memperkeruh aksi demonstrasi terkait kasus rasisme akibat dari ujaran kebencian yang dapat memancing kemarahan massa di media sosial, Facebook telah menghapus sekitar 200 akun media sosial yang terkait dengan kelompok supremasi kulit putih (VOI, 2020).

Dijelaskan oleh Fishman, seorang direktur anti-terorisme dan kebijakan organisasi berbahaya 
Facebook bahwa kelompok - kelompok ini berencana menggerakkan pendukung dan anggota untuk secara fisik hadir dalam aksi unjuk rasa dan dalam beberapa kasus dipersiapkan untuk membawa senjata (VOI, 2020).

Berdasarkan laporan dari Associated Press, 200 akun yang dihapus Facebook ini masih berkaitan dengan kelompok supremasi kulit putih, seperti Proud Boys dan American Guard. Kedua akun tersebut telah dikecal dari Facebook akibat melanggar aturan mengenai pelarangan ujaran kebencian. Facebook pun memang telah memonitor berbagai akun yang berupaya untuk semakin memperkeruh aksi protes 'Black Lives Matter' di Amerika Serikat (VOI, 2020).

Peneliti merasa bahwa langkah yang diambil Facebook untuk menekan kasus rasisme dengan menambahkan fitur Facebook News Room dan memberikan label pada media yang diduga dikendalikan oleh negara serta melakukan penghapusan 200 akun yang terkait dengan kelompok supremasi kulit putih sudah tepat, namun di sisi lain pun menimbulkan kekhawatiran bahwa pemberian label ini juga meluas ke media lain, tidak hanya terjadi pada media yang dikendalikan oleh suatu negara seperti Rusia, China, Korea Utara, dan Iran.

Oleh sebab itu, maka penelitian ini akan mengkaji mengenai bagaimana pembentukan Facebook News Room dalam menekan kasus rasisme yang berfokus pada pemberian label oleh Facebook pada media asing dan tujuan penelitian ini untuk mengetahui pembentukan dan efektivitas Facebook News Room dalam menekan kasus rasisme yang berfokus pada pemberian label oleh Facebook pada media asing.

\section{METODE PENELITIAN}

Penelitian ini menggunakan pendekatan penelitan kualitatif deskriptif. Penelitian kualitatif adalah sebuah penelitian yang mengeksplorasi dan memahami suatu makna dari masalah sosial yang berkaitan dengan individu atau kelompok (Creswell, 2009, p.29). Sedangkan jenis penelitian deskriptif merupakan suatu penelitian yang mencoba mendefinisikan dan menjabaran masalah dengan menggunakan kata - kata atau angka untuk menyajikan sebuah gambaran yang berfokus pada jawaban dari pertanyaan mengenai aktifitas sosial tentang siapa, kapan, dimana, dan bagaimana (Neuman, 2014, p.38).

Unit Analisis yang peneliti gunakan dalam penelitian ini adalah observasi. Pada observasi, peneliti mengobservasi pembentukan Facebook News Room dalam menekan kasus rasisme yang berfokus pada pemberian label oleh Facebook pada media asing. Metode pengumpulan data pada penelitian ini menggunakan data sekunder yang berasal dari studi literatur atau berita Facebook di media Indonesia maupun media asing.

\section{HASIL DAN PEMBAHASAN}

TEORI GATEKEEPING BRUCE WESTLEY DAN MALCOM MCLEAN

Bruce Westley dan Malcom Mclean merupakan peneliti yang model komunikasinya berpengaruh dan banyak digunakan untuk mengungkapkan riset-riset komunikasi massa dengan gambaran yang spesifik. Gambaran komunikasi yang dijelaskan dengan situasi gatekeeping dimana model ini sangat menekankan 
para gatekeeper dalam proses komunikasi massa. Westley dan Maclean menggambarkan konsep gatekeeper dalam proses gatekeeping komunikasi massa kedalam bentuk model sebagai berikut:

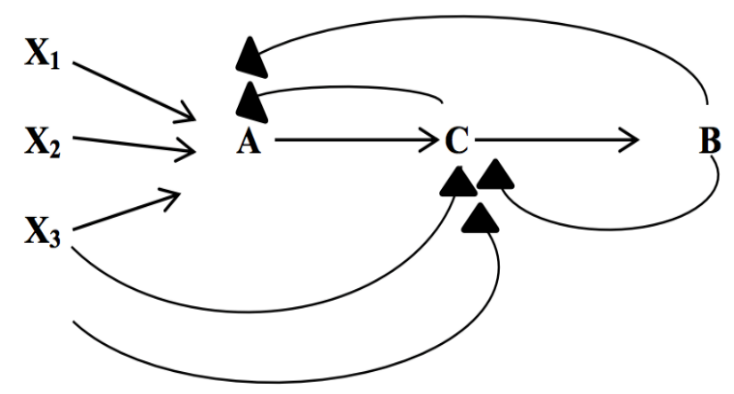

Sumber: Ardianto, 2007

Gambar 1. Proses Gatekeeping Westley dan Maclean.

Keterangan:

$\mathrm{X}=$ Sumber Informasi

$\mathrm{A}=$ Pengirim Pesan / Komunikator

$\mathrm{C}=$ Gatekeeper

$\mathrm{B}=$ Audience

$\mathrm{F}=$ Feedback

Sumber informasi (X) biasanya mengacu kepada sumber informasi mengenai sebuah peristiwa, kejadian, atau pertanyaan seseorang. Gatekeeper merupakan bagian dari institusi media massa, dimana hasil kerjanya memiliki efek yang positif pada kualitas pesan dan berita yang disampaikan kepada publik. Model Westley dan Maclean menjelaskan jika komunikator (A) menyediakan informasi (X) dari luar dan informasi tersebut akan segera diseleksi hingga kemudian dapat diterima oleh para audien (B). Peran (C) sebagai gatekeeper, memungkinkan adanya tambahan informasi dari (A) sehingga dapat berkontribusi terhadap (X) untuk dikonsumsi oleh audience (Ardianto, 2007, p. 38).

Ketika adanya informasi, penjaga gerbang atau media atau yang disebut dengan gatekeeper kemudian menciptakan pesannya sendiri (X) yang ia kirimkan kepada khalayak penerima atau audiens (B). Maka terbentuklah suatu sistem penyaringan pesan karena khalayak tidak memperoleh informasi langsung dari sumbernya, namun melainkan dari media yang menyaring informasi dari berbagai sumber tersebut. Media mendapat input informasi dari reporter yang turun langsung ke lapangan atau menemui narasumber. Dalam komunikasi massa, umpan balik dapat mengalir melalui tiga arah yakni dari penerima ke penjaga gerbang, dari penjaga gerbang ke sumber, dan dari penerima langsung ke sumber (Mulyana, 2011, p. 158).

Gatekeeping kemudian dicetuskan oleh Westey dan Maclean sebagai sebuah proses produksi berita di media massa yang biasanya dilakukan didalam ruang redaksi. Dari teori gatekeeping ini dapat dilihat proses penyampaian berita kepada audiens merupakan hasil kerja dari reporter sampai meja redaksi. Semua saluran media massa saat ini memiliki sejumlah gatekeeper. Gatekeeper dapat menghapus pesan dan juga bisa memodifikasi serta menambah pesan yang kemudian akan disebarkan kepada audiens. Gatekeeper juga dapat menghentikan sebuah informasi dan tidak membuka "pintu gerbang" bagi keluarnya informasi atau pesan yang lain (Nurudin , 2013, p. 157).

Proses gatekeeping dalam model Westley dan Maclean (1957) menyajikan komunikator dalam 
pengaturan sistem komunikasi. Adapun komunikator memiliki perannya yakni sebagai:

\section{The Advocacy Role}

Komunikator memiliki perannya sebagai advokasi yakni dapat memilih dan mengirimkan pesan secara sengaja. komunikator (A) berusaha untuk mempengaruhi individu lain di lingkungan baik secara langsung ataupun tidak langsung. Dalam komunikasi massa peran A dapat dimainkan oleh sumber informasi dengan sengaja seperti partai politik, departemen humas dari sebuah perusahaan, atau seseorang dalam sebuah organisasi media itu sendiri.

Di Indonesia, peran advokasi dapat mengacu pada Undang-undang Republik Indonesia Nomor 32 Tahun 2002 Pasal 36 Bab IV Tentang Penyiaran dan Pelaksanaan Siaran. Pasal 36 juga menyebutkan larangan isi siaran yang bersifat fitnah, menghasut, menyesatkan dan atau bohong, menonjolkan unsur kekerasan, cabul, perjudian, penyalahgunaan narkotika dan obat terlarang serta, mempertentangkan suku, agama, ras, dan juga antar golongan.

\section{The Channel Role}

Peran saluran media tertuju pada peran $\mathrm{C}$ selaku gatekeeper dalam proses gatekeeping yang memiliki karakter yang disengaja, tujuannya adalah untuk menyediakan masyarakat dengan informasi dan untuk bertindak sebagai perantara antara A dan masyarakat. Yang dimaksud dengan saluran yakni sarana untuk menyampaikan pesanpesan dari komunikator kepada audien. Peran ini biasanya diisi oleh wartawan yang merupakan bagian dari organisasi media massa. Model Wesley dan Maclean menggambarkan peran $\mathrm{C}$ (sebagai gatekeeper) dalam kaitannya peran A, sebagai yang tidak disengaja karena inividu yang bertindak dalam peran $\mathrm{C}$ tidak dalam kepentingan mereka sendiri melainkan kepentingan organisasi media.

\section{The Behavioral Role}

Peran sistem perilaku dimaksud adalah individu, kelompok, atau sistem sosial yang membutuhkan dan menggunakan informasi tentang lingkungan mereka untuk membantu memenuhi kebutuhan dan membantu memecahkan masalah. Peran ini dipegang oleh Audien (B) anggota masyarakat mencakup pembaca, pemirsa dan pendengar (Werner, 2014, p. 61).

Teori yang dipergunakan pada penelitian ini adalah studi Gatekeeping dari Westley dan Maclean. Mereka merumuskan model komunikasi massa dengan menambahkan fungsi penjaga gerbang (C) kepada fungsi sumber (A) dan penerima (B). Mereka menduga bahwa peran penjaga gerbang adalah menyampaikan pesan yang sesuai dengan atau diinginkan oleh si penerima.

Telah diketahui bahwa Facebook Newsroom dibuat untuk memberikan label terhadap berita atau informasi yang tersebar di platform mereka. Fitur ini telah melewati uji coba fitur pada Oktober 2019, namun baru saja launching di AS pada tanggal 5 Juni 2020. Melihat survei yang dilakukan oleh PricewaterhouseCoopers $(\mathrm{PwC})$ Indonesia dan Institute for Development of Economics and Finance (INDEF), 82\% responden mengaku mencari berita melalui Facebook (Fajri, 2019). 
Jenis Informasi dalam Facebook yang Dicari Individu

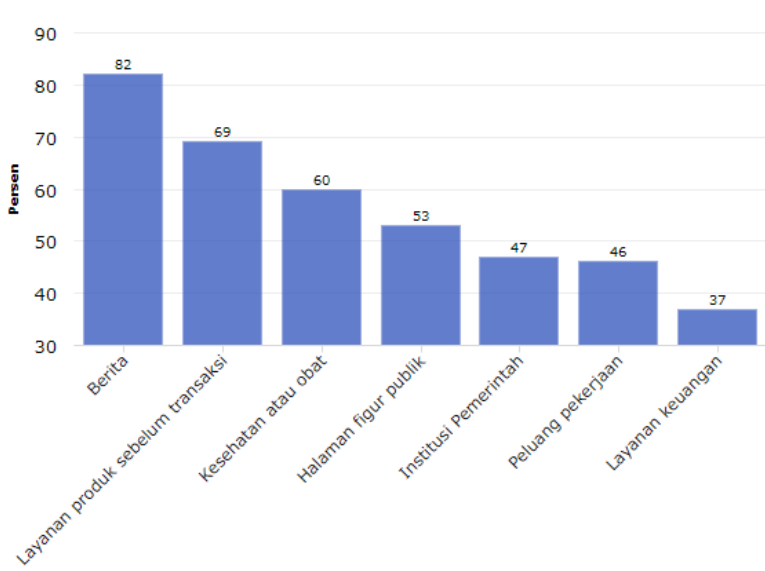

Sumber : Fajrin, 2019

Gambar 2. Hasil Survei

PricewaterhouseCoopers (PwC) Indonesia.

Ini menjadi penyebab utama bahwa peran Facebook menjadi penting untuk menyiapkan fitur yang bisa menjadi penyaring informasi yang akan dikonsumsi oleh publik. Hal ini juga akan meredam citra Facebook sebagai tempat beredarnya hoaks selama ini.

Facebook Newsroom hadir sebagai penjaga gerbang yang dibuat oleh Facebook untuk menyaring dan melabeli berita yang nantinya akan disediakan untuk pengguna. Facebook memiliki redaksi yang bernama Facebook Newsroom yang berfungsi untuk menyaring informasi politik, rasisme, bahkan bertugas memberi label pada 'media asing'. Mereka yang akan menentukan informasi apa yang layak tayang untuk pengguna Facebook dan melaporkan akun yang dapat menimbulkan kemarahan publik.

Dengan adanya fitur ini, Facebook akan bersaing dengan aggregator, seperti Line Today, Kurio, BaBe, UC News (Fajrin, 2019).

Dalam unggahan blog Facebook Newsroom, VP, Global News Partnerships Facebook Campbell
Brown dan Product Manager News Facebook Mona Sarantakos mengatakan bahwa ada artikel berita yang muncul di beranda pengguna. Hanya, belum ada konfirmasi apakah fitur ini akan dibawa ke Indonesia (Fajrin, 2019).

"Kami ingin memberi orang lebih banyak kontrol atas berita yang mereka lihat, dan kemampuan untuk mengeksplorasi lebih banyak minat berita mereka, langsung di dalam aplikasi Facebook," kata Brown dan Sarantakos.

Di dalam blog tersebut Brown dan Sarantakos juga mengatakan, bahwa tab 'berita' atau Facebook Newsroom dikembangkan melalui konsultasi dengan media dengan harapan bisa menangkal hoaks. Facebook memilih untuk bermitra dengan kantor media yang diangaap kredibel, seperti Washington Post, BuzzFeed News, NBC, USA Today, Los Angeles Times, Wall Street Journal, dan Business Insider (Fajrin, 2019).

John R. Bittner (1996) mengistilahkan gatekeeper sebagai individuindividu atau kelompok orang yang memantau arus informasi dalam sebuah saluran komunikasi massa. Gatekeeper berperan penuh untuk menentukan tayangan atau peristiwa apa yang akan ditampilkan di media. Di sini terlihat, bahwa fungsi media di tengah-tengah masyarakat. Media ikut andil besar dalam mempengaruhi perilaku dan opini masyarakat. Dengan demikian, medianya sendiri berperan sebagai penjaga gawang di tengah-tengah kebutuhan masyarakat terhadap informasi.

Aktivitas yang dilakukan oleh Gatekeeper anatara lain: 
- Penapisan informasi bersifat subjektif dan personal.

- Penapisan informasi membatasi apa yang ingin diketahui oleh pembaca.

- Penapisan informasi menjadi suatu aktivitas yang tidak bisa dihindari oleh media.

Berdasarkan model, maka dapat digambarkan cara

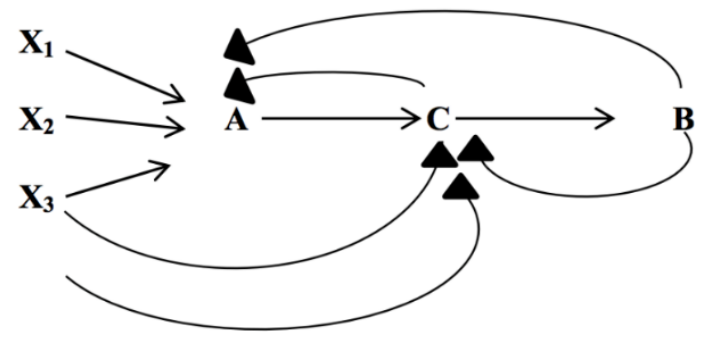

Facebook menyaring informasi seperti,

$\mathrm{X}=$ Netizen/ narasumber

$\mathrm{A}=$ Akun media dari seluruh dunia

$\mathrm{C}=$ Facebook Newsroom

$\mathrm{B}=$ Pengguna Facebook

Faktor utama Facebook Newsroom dibentuk adalah merebaknya konten kebencian dan rasisme di Facebook membuat banyak perusahaan seperti Starbucks dan Lego untuk menangguhkan sementara pemasangan iklan di platform media sosial Facebook. Sebelum ini, Unilever, CocaCola, hingga Honda sudah lebih dulu menyatakan diri mencabut semua iklannya yang ada di Facebook dan Instagram.

Walaupun Mark Zuckerberg mengaku tetap optimis bahwa pengiklan tersebut akan kemabali, namun sampai saat ini sudah ada 600 perusahaan yang memboikot Facebook dan berhenti menaruh iklan di platform tersebut. 400 perusahaan di antaranya adalah merek terkemuka seperti Lego, Addidas, dan Levi's. Peristiwa ini menyebabkan saham Facebook turun hingga 8,3 persen dan terkoreksi hingga 58 miliar dolar AS atau sekitar Rp841 triliun dalam bursa perdagangan, di bulan Juni.

Menurut laporan Bloomberg, aksi boikot iklan ini membuat kekayaan Mark Zuckerberg berkurang drastis sebanyak 7,21 miliar dolar AS atau sekitar Rp103,5 triliun dalam 24 jam terakhir. Hal tersebut membuat Zuckerberg turun ke posisi empat dalam daftar orang terkaya di dunia, di bawah bos Louis Vuitton Bernard Arnault, pendiri Microsoft Bill Gates, dan CEO Amazon Jeff Bezos. (Elfira, 2020)

Facebook Newsroom bertugas untuk memberikan label laman 'media asing' berdasarkan berbagai faktor, mulai dari informasi kepemilikan akun dan sumber pendanaan media, transparansi di sekitar tulisan hingga kebijakan koreksi dan sistem akuntabilitas media berita tersebut. Meski begitu laman tersebut masih bisa beroperasi secara independen, berdasarkan kebijakan undangundang kebebasan pers dan penilaian yang kredible dari media asing tersebut (VOI, 2020).

Facebook Newsroom telah melabeli beberapa laman dan post dari outlet media asing yang dianggap, karena dianggap menyebarkan propaganda di AS. Beberapa di antaranya termasuk Sputnik dan RT yang merupakan media asing asal Rusia.

Kami melakukan pengamatan dengan menggunakan VPN tentang cara kerja Facebook Newsroom yang hanya dirilis di Amerika Serikat. Facebook Newsroom yang berfungsi sebagai penjaga gerbang telah menyiapkan beberapa fitur seperti Today's Stories, Personalization, Topic Section, Your Subscriptions, dan Controls.

\section{Today's Stories}


Dalam fitur ini, redaksi Facebook Newsroom akan memilih berita yang kemungkinan diperlukan oleh user dalam sepanjang hari.

\section{Personalization}

Fitur penyajian berita sesuai minat pengguna. Redaksi akan menyusun rekomendasi berdasarkan topik yang dibagikan dan diikuti, sehingga pengguna dapat menemukan minat dan topik baru.

\section{Topic Section}

Pengguna dapat memanfaatkan fitur ini untuk memilih berita secara praktis berdasarkan topik yang mereka cari. Facebook Newsroom memiliki 5 kanal di dalamnya, yaitu bisnis, hiburan, kesehatan, sains dan teknologi, dan olahraga.

\section{Your Subscriptions}

Fitur ini memudahkan pengguna untuk melihat berita langganan berbayar pada akun mereka. Redaksi akan menautkan akun berita tersebut pada beranda akun pengguna.

\section{Controls}

Pengguna juga dapat mengatur sendiri berita yang ingin mereka lihat, atau berita yang tidak ingin mereka lihat. Redaksi Facebook memberikan kesempatan pada pengguna untuk menyaring berita yang mereka butuhkan.

\section{Menilai Efektivitas Facebook Newsroom}

Setelah Facebook Newsroom dirilis, rumah produksi film animasi Walt Disney Co memutuskan bergabung ke dalam jajaran perusahaan dunia yang memboikot iklan platform media sosial Facebook dan Instagram. Disney merasa khawatir tentang kebijakan Facebook yang masih membiarkan konten-konten negatif. (VOI,2020)
Sudah hampir satu bulan berlalu Facebook masih menerima keluhan dari pihak sponsor, bahkan ada rumor beredar bahwa Facebook dicurigai sebagai platform yang melindungi segala aktivitas Donald Trump, termasuk pada unggahannya yang menunjukkan ujaran kebencian. Walaupun CEO Facebook, Mark Zuckerberg membantah hal tersebut, namun citra itu masih ada dan terbentuk hingga banyak pemasang iklan akhirnya beramai-ramai mencabut dana sponsornya di platform tersebut.

Kasus lainnya adalah permasalahan data sharing dengan Hongkong. Pemerintah Hongkong menawarkan kerja sama dengan pihak Facebook untuk meredam gerakan anti-pemerintah. Termasuk penghapusan media sosial jika postingan para aktivis dinilai subversif oleh pemerintah. Namun Mark Zuckerberg dengan keras menolak (VOI, 2020).

"Kebebasan berekspresi adalah hak asasi manusia yang mendasar dan mendukung hak orang untuk mengekspresikan diri tanpa rasa takut akan keselamatan mereka atau dampak lainnya," Mark Zuckerberg (VOI, 2020).

Berdasarkan pengamatan, Facebook menolak permintaan tersebut karena dampak dari penerapan Undang-Undang (UU) Keamanan Nasional baru yang diterapkan pada 1 Juli 2020. Hal ini merupakan langkah baik untuk membersihkan citra Facebook dari sisi keamanan data (VOI, 2020).

Fakta lainnya yang kami temukan, adanya kampanye "Stop Hate for Profit" ini salah satu gerakan yang meggunakan boikot sebagai alat politik yang sedang marak saat ini. Inti kampanye ini adalah bisnis mestinya tak mengambil 
keuntungan dari konten yang dinilai mempromosikan kebencian. Gerakan ini menyatakan bahwa Facebook tidak ingin menghapus muatan-muatan berbau rasis dan ujaran kebencian dari platform mereka, padahal Facebook Newsroom saat itu sudah launching di AS (BBC, 2020).

Kampanye tersebut berupaya meyakinkan beberapa perusahaan besar untuk menarik iklan mereka dari Facebook dan beberapa perusahaan media sosial lain.Beberapa yang sudah melakukannya adalah Ford, Adidas dan HP. Mereka akhirnya bergabung dengan brand ternama yang sudah terlebih dulu melakukannya termasuk Coca-Cola, Unilever dan Starbucks. Situs Axios juga mengatakan bahwa alasan Microsoft menunda iklan di Facebook dan Instagram karena adanya kekhawatiran terhadap postingan yang tak pantas, namun mereka tidak menyebutkan dengan rinci maksud tersebut. David Cumming dari Aviva Investors mengatakan bahwa hilangnya kepercayaan dan anggapan ketiadaan panduan moral bisa "menghancurkan bisnis". Sepertinya Facebook mulai kehilangan kepercayaan dari pengiklan (BBC, 2020).

Kampanye boikot iklan Facebook, \#StopHateForProfit, semakin meluas. Tercatat lebih dari 500 perusahaan telah menyatakan dukungannya terhadap pemboikotan ini. Kampanye ini telah membuat harga saham Facebook anjlok meskipun mayoritas dari 100 pengiklan terbesar Facebook belum bergabung dalam kampanye tersebut. Pemboikotan yang diberi nama \#StopHateForProfit ini muncul hanya beberapa pekan setelah sejumlah karyawan
Facebook menggelar mogok kerja virtual pada 1 Juni 2020. Para aktivis di kampanye tersebut mengkritik Facebook karena telah melakukan penyebaran kebencian yang luas di platformnya (Anjar, 2020).

Facebook juga dinilai membiarkan unggahan berisi hasutan untuk melakukan kekerasan terhadap demonstran. Kampanye ini menyerukan agar grupgrup pribadi di Facebook yang menjajakan kebencian, misinformasi, atau konspirasi bisa segera dihapus. Facebook diminta untuk menyerahkan laporan dari auditor independen tentang tindakan yang telah diambil perusahaan. Saat ini Facebook tetap berada di tengah sorotan publik. Mereka menuntut secara responsif, meskipun perusahaan-perusahaan yang mengikuti kampanye \#StopHateForProfit diduga lebih termotivasi karena menyelamatkan citra dari pada keinginan untuk menangkal misinformasi dalam iklan Facebook (Anjar, 2020).

Pada akhirnya, Facebook mengambil jalan tengah dengan mengumumkan bahwa mereka akan memberikan label pada unggahan politikus yang melanggar kebijakan platform namun dinilai masih layak tayang. Keputusan ini berpegang pada prinsip-prinsip kebebasan berbicara yang dianut Facebook. Tapi sebagian orang menilai itu dilakukan untuk menghindari kemarahan Trump. Zuckerberg meyakini bahwa, untuk menangkal ujaran yang berbahaya, diperlukan "more speech", bukan penyensoran. Karena itu, ujaran kebencian yang beredar cuma diberi label, tidak dicabut (Anjar, 2020).

Berbeda dengan konten-konten yang lebih ekstrem, Facebook berjanji akan menghapusnya. 
Zuckerberg mengatakan bahwa unggahan yang mengarah pada kekerasan atau menghilangkan hak orang untuk memilih tidak akan ditoleransi, walaupun dibuat oleh politikus termasuk Trump. Facebook pun menulis surat terbuka yang menyatakan mereka "tidak mendapatkan profit dari kebencian". Facebook berargumen bahwa mereka menghapus ujaran kebencian lebih cepat ketimbang YouTube dan Twitter (Anjar, 2020).

Tapi langkah-langkah itu tidak membuat kampanye \#StopHateForProfit terhenti. Bahkan, survei World Federation of Advertisers memprediksi sepertiga pengiklan terbesar Facebook bakal segera bergabung dalam pemboikotan itu. Dengan meningkatnya eksistensi dari gerakan ini, langkah-langkah yang lebih berarti perlu dilakukan oleh Facebook. Apalagi, selama bertahun-tahun, Facebook terus memiliki masalah yang sama, yakni misinformasi dan ujaran kebencian (Anjar, 2020).

\section{SIMPULAN}

Facebook Newsroom merupakan strategi Facebook untuk menyaring informasi atau berita yang dikonsumsi oleh penggunanya. Namun setelah satu bulan launcing di Amerika Serikat, Facebook masih dinilai memiliki masalah yang sama yakni misinformasi dan tempat seseorang menyebarkan ujaran kebencian. Sampai saat ini dapat dinyatakan bahwa tindakan ini tidak cukup berarti untuk meredam amarah publik dan mengembalikan kepercayaan dari pengiklan itu sendiri. Bila tidak ada perubahan dalam waktu dekat, Facebook bisa saja ditinggalkan oleh pengguna karena kehilangan kredibilitas.

\section{DAFTAR PUSTAKA}

Amali, Z. (2020, Juni 3). Pembunuhan George Floyd: Dunia Mengecam Rasisme di AS.

Diakses dari https://tirto.id/pembunuhan-georgefloyd-dunia-mengecamrasisme-di-as-fEBS

Anjar, A. (2020, Juli 07). CekFakta \#66 Ramai-ramai Boikot Iklan Facebook. Diakses dari https://newsletter.tempo.co/read/1362230/cekfakt a-66-ramai-ramai-boikot-iklan-facebook

Ardianto, E,. dkk. (2007). Komunikasi Massa: Suatu Pengantar, Edisi Revisi. Bandung, Indonesia: Simbioasa Rekatama Media

Ben. (2020, Juli 06). WhatsApp and Telegram will not hand over user data to Hong Kong authorities. Diakses dari https://9to5mac.com/2020/07/06/whatsapp-and telegram/

BBC. (2020, 01 Juli). Facebook diboikot gara-gara dianggap enggan atasi ujaran kebencian,mapakah Facebook akan mati? Diakses dari https://www.bbc.com/indonesia/majalah53235065

Creswell, W. John. (Eds.). 2009. Research Design: Qualitative, Quantitative and Mixed Methods Approaches. Los Angeles, California : Sage Publication.

Fajrin, P. A. M. (2019, November 21). Mengenal Cara Kerja Fitur Facebook News Tangkal Hoaks. Diakses dari https://katadata.co.id/pingitfajrin/digital/5e $9 \mathrm{a} 4 \mathrm{c} 55$ 30215/mengenal-cara-kerja-fitur-facebook-newstangkal-hoaks

Iswara, A. J. (2020, Juni 2). Demo George Floyd Bertajuk Black Lives Matter, Apa Artinya?. Diakses dari https://www.kompas.com/global/read/2020/06/02/ 180619270/demo-george-floyd-bertajuk-blacklives-matter-apa-artinya?page $=$ all

Mulyana, D. (2011). Ilmu Komunikasi. Bandung: PT. Rosdakarya

Neuwman, W. L. (2014). Social Research Methods: Qualitative and Quantitative

Approachers (Eds 7). Harlow, United Kingdom : Pearson Education Limited

Nurudin. (2013). Pengantar Komunikasi Massa. Jakarta: Rajawali Pers

Putri, V. M. (2019, April 02). Facebook Ungkap Cara Kerja Algoritma News Feed. Diakses dari https://inet.detik.com/cyberlife/d-

4494784/facebook-ungkap-cara kerjaalgoritma-news-feed

VOI. (2020, Juni 10). Facebook Take Down 200 Akun yang Terkait Kelompok Rasisme. Diakses dari https://voi.id/teknologi/7097/facebook-i-takedown-i-200-akun-yang-terkait-kelompok-rasisme 
VOI. (2020, Juni 5). Facebook Mau Kontrol Laman Pemberitaan Media Asing di Platformnya. Diakses dari https://voi.id/teknologi/6845/facebook-maukontrol-laman-pemberitaan-media-asing-di-iplatform-i-nya

VOI. (2020, 29 Juli) Disney Akhirnya Ikut Boikot Iklan di Facebook dan Instagram. Diakses dari https://voi.id/teknologi/9053/disney-akhirnyaikut-boikot-iklan-di-facebook-daninstagram\#: :text=Bagikan\%3A,media\%20sosial $\% 20$ Facebook\%20dan\%20Instagram.

VOI. (2020, 8 Juli 2020) Facebook cs Ogah Turuti Permintaan Hong Kong untuk Berbagi Data Penggunanya. Diakses dari https://voi.id/teknologi/8429/facebook-cs-ogahturuti-permintaan-hong-kong-untuk-berbagi-datapenggunanya

Werner, J. Severin., dkk. Communication Theories: Origins, Methods, and Uses in the Mass Media. Longman: Library of Congress Cataloging-inPublication 